\title{
AUTOMATION AND INTEGRATION OF OFFER-PROCESSING
}

\author{
Militzer, J.; Teich, T.; Unger, K. \& TrautMann, J.
}

Abstract: As a result of globalization, customers are able to source from a wider range of suppliers. This leads to a growing pressure especially on SME's to align their businesses to the needs of their market contrary. To accomplish this goal, companies need to be more agile, flexible and adaptive to a changing environment.

To cope with this environment, a key element for companies is a fast and detailed response to inquiries of their customers. Automation and Integration of CAD (Computer Aided Design), CAM (Computer Aided Manufacturing) and CAP (Computer Aided Planning) is necessary to accomplish this goal. Automation in this context means an automated process planning and work scheduling, with specific connections to Integration. Integration correlates to a functional, computer interpretable description of resources which describes the ability to create value of a company.

Key words: $C A D, C A P, C A M$
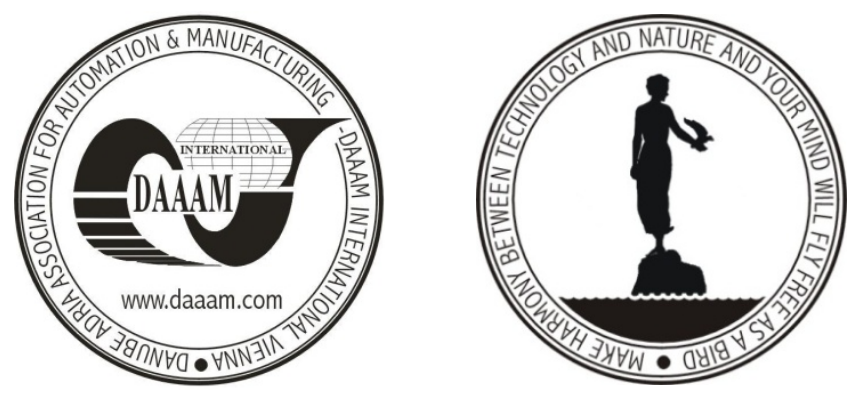

Authors' data: Militzer, J[oerg]*; Prof. Teich, T[obias]*; Unger, K[atja $]^{* *}$; Trautmann, J[uergen]***, *WHZ, Scheffelstraße 30, 08066, Zwickau, DE, **University of Applied Sciences Zwickau, Dr.-Friedrichs-Ring 2a, 08056, Zwickau, DE, ***VW Sachsen GmbH, Glauchauer Straße 40, 08058 Zwickau, DE, joerg.militzer@fh-zwickau.de, tobias.teich@fh-zwickau.de, katja.unger@fh-zwickau.de, juergen.trautmann@volkswagen.de

This Publication has to be referred as: Militzer, J[oerg]; Teich, T[obias]; Unger, K[atja] \& Trautmann, J[uergen] (2008). Automation and Integration of OfferProcessing, Chapter 40 in DAAAM International Scientific Book 2008, pp. 477-484, B. Katalinic (Ed.), Published by DAAAM International, ISBN 978-3-901509-66-7, ISSN 1726-9687, Vienna, Austria

DOI: $10.2507 /$ daaam.scibook.2008.40 